\title{
ERGONOMIC FACTORS THAT PROMOTE THE FORMATION OF REHABILITATION CENTERS FOR CHILDREN WITH DISABILITIES
}

Malashenkova V. A., candidate of architecture, PHD department of Architecture of building and structure

тел. +38(095)-153-77-75, +38(066)-276-40-06

e-mail: viklituchka@gmail.com; ID ORCIDE: https://orcid.org/0000-0001-8228-2467

Glinin D. Y., asisstent lecturer, department of Urban Planning

Odessa State Academy of Civil Engineering and Architecture

Abstract: The article presents the main ergonomic factors that contribute to the formation of architecture. The use of ergonomic requirements in the field of architectural design is due to the problems of architectural ergonomics, which are associated with the formation of an environment that allows the child to use his abilities and respond to his individual requests. Based on the studies, 4 main ergonomic factors are identified and their detailed characteristics are given.

One of the most important subsystems of the social sphere of any state is nurturing, treatment and education of children with various types of disabilities and limitations, which determines the potential of social, economic and cultural development.

In our country we are actively searching for the solutions that allow flexible use of the building, taking into account emerging changes in the forms and methods of rehabilitation and training. The solution of this problem is to create open internal, transformed space for children's rehabilitation centers.

In fact the features and specifics of the rehabilitation is a research institution in which there is a research part and it carries out the work in each individual situation, and in the activity of the specialist as a whole, and without focusing on this aspect, this work becomes a simple formality.

The application of ergonomic requirements in the field of environmental architectural design highlights the problems of architectural ergonomics, associated with the formation of our immediate surrounding, in accordance with individual requests of the person, taking into account the facilitation of the fulfillment of human life functions. Against this background, it is necessary to be very responsive to creating of the architectural environment for children with disabilities. Ergonomic factors are the most important forming factors for particular architecture that will affect the treatment and rehabilitation of such children.

Thus, the ergonomic factors, that affect the formation of rehabilitation centers for the children with disabilities, can be divided into 4 groups:

- spatial and anthropometric requirements (dimension and size of the equipment and furniture, geometric parameters of space, spatial human behavior, human anthropometric characteristics);

- determination of number of storeys;

- barrier-free architecture;

- psycho-physiological environment.

Correcting the architectural environment would reduce the problem of children with disabilities. It should be noted that equipping the environment with stationary supporting devices does not solve the problem of physical defect compensation. The environment -obstacles $\|$ for such children are: long way, difficult route, irrational movement, interaction with furniture, etc.

According to the research, the children and the teachers are forced to walk up to a 40-floor height every day. Of course, this has a negative effect on children's health. It is established that as a result of 5-floor rising, the pulse rate and blood pressure indicators change significantly, and the recovery occurs only in 10-20 minutes. 
Most of the existing centers are located in four-, five-storey buildings. Although the hygienists in special children's rehabilitation centers have not performed similar studies, it is correct to assume that the negative impact of these factors on them will increase taking into account the peculiarities of physical growth and development of children with disabilities. The issue of identifying the optimum number of stories in a building is closely connected with the organization of connection between the classrooms and the school site.

When organizing the environment during the design it is necessary to foresee and ensure: the shortest accessibility to the rooms, actively used by the children; reduction of movement routes, exclusion of difficult routes; obstacle clearing on the path; the use of specially designed furniture, effective trauma protection of the children.

It should be noted that the use of such elements as paintings, reproductions, photos, music, color, can significantly improve the mental health of patients and affect the working efficiency of the staff. However, when choosing colors for walls, doors, furniture, for the purpose of special marking, it is necessary to take into account the difficulties in their discrimination for many people, in particular, for elderly patients, patients with mental disorders and those who have color discrimination [6, p. 14].

Medical equipment, that is easy to transform and takes into account the different levels of users' mobility, will help to create comfortable, safe conditions and lighten the work of the staff. For example, a height-adjustable specialist seating is accessible for the children with muscleskeleton disorder and, at the same time, reduces staff efforts.

Creating barrier-free architecture is one of the topical problems in building an accessible architectural environment for children with disabilities. This factor should take into account the needs of those children who require specific conditions, who have trouble in self-care and mobility. The first and most important requirement for creating a barrier-free environment is the concept of -universal designll.

The second most important requirement is acting according to a continuity principle of the barrier-free architectural environment. No barriers, the elements, that make impossible or significantly complicated movement and self-care, should be encountered in all the spheres of human activity, and first of all in the path of movement. It is especially important to follow the continuity principle in the areas where the child is most often.

State building codes and design guides help the architects and designers make space for the children with disabilities as accessible, comfortable, and understandable as possible. Nowadays, universal design in our country is at the level of development, but this is the first steps towards improving the architectural environment for children with disabilities.

Key words: rehabilitation center for children, children with disabilities, urban planning features, accommodation in urban structure, zoning territory of the center.

\section{ЕРГОНОМІЧНІ ЧИННИКИ, ЩО СПРИЯЮТЬ ФОРМУВАННЮ РЕАБІЛІТАЦІЙНИХ ЦЕНТРІВ ДЛЯ ДІТЕЙ 3 ОБМЕЖЕНИМИ МОЖЛИВОСТЯМИ}

Малашенкова В. О., канд. арх., доцент кафедри архітектури будівель та споруд тел. +38 (095)-153-77-75, +38 (066)-276-40-06 e-mail: viklituchka@gmail.com;ID ORCIDE: https://orcid.org/0000-0001-8228-2467

Глінін Д. Ю., асистент кафедри містобудування

Одеська державна академія будівниитва та архітектури.

Анотація: В статті розглянуті основні ергономічні чинники, які сприяють формуванню архітектури реабілітаційних центрів для дітей з обмеженими можливостями. Застосування ергономічних вимог в області середовищного архітектурного проектування виділяє проблеми архітектурної ергономіки, пов'язані з формуванням середовища, яке оточує дитину з обме- 
женими можливостями та відповідає ії індивідуальним запитам. На основі проведеного дослідження виділено 4 основних ергономічних чинника та надані їх детальні характеристики. Ключові слова: реабілітаційні центри, ергономічні чинники, методика дослідження, центри для дітей з обмеженими можливостями, ергономіка.

\title{
ЭРГОНОМИЧЕСКИЕ ФАКТОРЫ, КОТОРЫЕ СПОСОБСТВУЮТ ФОРМИРОВАНИЮ РЕАБИЛИТАЦИОННЫХ ЦЕНТРОВ ДЛЯ ДЕТЕЙ С ОГРАНИЧЕННЫМИ ВОЗМОЖНОСТЯМИ
}

\author{
Малашенкова В. А., канд. арх., доцент кафедры архитектуры зданий и сооружений \\ тел. +38 (095)-153-77-75, +38 (066)-276-40-06 \\ e-mail:viklituchka@gmail.com; ID ORCIDE: https://orcid.org/0000-0001-8228-2467 \\ Глинин Д. Ю., ассистент кафедры градостроительства \\ Одесская государственная академия строительства и архитектуры
}

Аннотация: В статье ррассматриваются основные эргономические факторы, способствующие формированию архитектуры реабилитационных центров для детей с ограниченными возможностями. Применение эргономических требований в области средового архитектурного проектирования выделяет проблемы архитектурной эргономики, связанные с формированием среды, которая окружает ребенка с ограниченными возможностями и отвечает его индивидуальным запросам. На основе проведенного исследования выделено 4 основных эргономических фактора и даны их детальные характеристики.

Ключевые слова: реабилитационные центры, градостроительные особенности, центры для детей с ограниченными возможностями, зонирование территории центров, размещение в городской структуре.

Formulation of the problem. The number of disabiled persons today is about $6 \%$ of the population of Ukraine, at the beginning of the year this was 2600000 . There are practically more than 156000 children with disabilities. Therefore, it is necessary to improve and facilitate their treatment, living conditions and services, as well as to engage in social life. Under the influence of social and scientific and technological progress, the architectural projects for rehabilitation centers are becoming more complex, requiring the development of new functions and their interconnections under well-grounded approach. The development and progressive reorganization of children's health are reflected in a change in the design principles of children's treatment centers. Modern architectural projects of children's rehabilitation centers must meet the current medical requirements, reflect the search for new solutions in the field of health, including the creation of an architectural environment that would eliminate the impact of adverse psychosomatic factors and contribute to the restoration to child's health. This is especially important for children with disabilities. Keeping in mind their limited movement in space, the influence of the architectural environment on the formation of the psychic conditions of children significantly increases, which must also be taken into account when creating such institutions. The important factor, influencing on the formation of the architectural environment, is the consideration of the developments in the field of ergonomics and design.

Analysis of recent research and publications. The following national developments are devoted to the conceptual and regulatory methodological problems regarding the living environment for adults and children with disabilities: V. Abazova, L. Barmashina, I. Kravchenko, Yu. Kolosov, A. Nikolskaya, O. Prokopenko, T. Savonyuk, S. Tokarev and foreign ones: V. Haita, V. Stepanov, N. Mezentseva.

The designing issues of the living environment of the people with disabilities in foreign countries have been studied according to such works: W. Meyer-Bohe, K. Jaranowska, M. Scolz and others, as well as the periodical publications. 
The purpose and tasks of the article are to identify and study the major ergonomic factors that influence on the formation of a specific architectural environment for children with disabilities; form the basic ergonomic factors and give them the characteristics.

One of the most important subsystems of the social sphere of any state is nurturing, treatment and education of children with various types of disabilities and limitations, which determines the potential of social, economic and cultural development. Modern needs for hidden resources are the driving force for the transformation of the social sphere towards the children with disabilities, the main purpose of which is to create equal opportunities for all citizens without exception [1, p. 23].

In our country we are actively searching for the solutions that allow flexible use of the building, taking into account emerging changes in the forms and methods of rehabilitation and training. The solution of this problem is to create open internal, transformed space for children's rehabilitation centers [1, p. 23].

In fact the features and specifics of the rehabilitation is a research institution in which there is a research part and it carries out the work in each individual situation, and in the activity of the specialist as a whole, and without focusing on this aspect, this work becomes a simple formality [2, p. 17].

Ergonomics - (from Greek ergon - work, nomos - law) - is a scientific discipline that studies comprehensively the functional skills of man in working processes, identifies the patterns of creating optimal conditions for high-performance activity. At the same time, ergonomics is the science that studies the means and ways of adapting space and objects to a person for safe and effective use on the basis of a person's mental and physical state. Broadly defined, ergonomics means a scientific field that searches the various objects that are in close contact with a person in his or her daily life, that is in everyday life [2, p. 5].

The application of ergonomic requirements in the field of environmental architectural design highlights the problems of architectural ergonomics, associated with the formation of our immediate surrounding, in accordance with individual requests of the person, taking into account the facilitation of the fulfillment of human life functions. Against this background, it is necessary to be very responsive to creating of the architectural environment for children with disabilities. Ergonomic factors are the most important forming factors for particular architecture that will affect the treatment and rehabilitation of such children.

Thus, the ergonomic factors, that affect the formation of rehabilitation centers for the children with disabilities, can be divided into 4 groups:

- spatial and anthropometric requirements (dimension and size of the equipment and furniture, geometric parameters of space, spatial human behavior, human anthropometric characteristics);

- determination of number of storeys;

- barrier-free architecture;

- psycho-physiological environment.

Through the studies of regulatory requirements, it was proved that the congenital deformities of the supporting-motor apparatus lead to the changes in metric data of children. The nature of these changes is heterogeneous, but the average anthropometric indicators generally fluctuate at the level of the norm. From this perspective, the anthropometric data of healthy child can be used to organize the environment for children with muscle-skeleton disorders. In this case, the possibility of individual aberrations should be considered in the areas of individual use and especially furniture. But at the same time, in the areas of individual use and furniture it is necessary to provide the possibility of changing the parameters in order to consider individual aberrations. The features of changed anthropometry of the children with disabilities are in the regulatory requirement on the flexible adaptation of the object environment (especially furniture) to the different sizing features of children [3, p. 76]. 
The variety of forms of lesions of the musculoskeletal system leads to increase actively used area around child's body, the life environment of such children is complexly transformed to enlarge the active area. Correcting the architectural environment would reduce the problem of children with disabilities. It should be noted that equiping the environment with stationary supporting devices does not solve the problem of physical defect compensation. The environment -obstacles\| for such children are: long way, difficult route, irrational movement, interaction with furniture, etc.

According to the research, the children and the teachers are forced to walk up to a 40-floor height every day. Of course, this has a negative effect on children's health. It is established that as a result of 5-floor rising, the pulse rate and blood pressure indicators change significantly, and the recovery occurs only in 10-20 minutes. There is the fact that the temperature and bacterial balance of the classrooms in the upper floors is deteriorating [3, p. 76].

Rescinding from the economy requirements at this stage, let's consider the factors that determine the number of stores of rehabilitation centers for purposes of hygiene and pedagogical requirements. There are six factors:

- changes in the activity of the child's body when walking up the stairs;

- change of temperature and bacterial air balance with increasing the number of stories;

- health effects of staying outdoors;

- movement speed of sick children horizontally and down the steps;

- organization of dressing rooms and exits from the building according to centralized or decentralized system;

- set time for evacuation of the children from the rooms to the school site [3, p. 77].

Most of the existing centers are located in four-, five-storey buildings. Although the hygienists in special children's rehabilitation centers have not performed similar studies, it is correct to assume that the negative impact of these factors on them will increase taking into account the peculiarities of physical growth and development of children with disabilities. The issue of identifying the optimum number of stories in a building is closely connected with the organization of connection between the classrooms and the school site.

When organizing the environment during the design it is necessary to foresee and ensure: the shortest accessibility to the rooms, actively used by the children; reduction of movement routes, exclusion of difficult routes; obstacle clearing on the path; the use of specially designed furniture, effective trauma protection of the children.

The elements of communication require a special solution - doorways, they create -crossing $\|$ of the borders between separate rooms [4].

The analysis of children's movement revealed the -permanentll obstacles around the building: door sills, raised structural elements (columns, structural down stands in halls, etc.), the furniture placed in the corridors (better placed it in recesses), doors that swing the hall (preferred rolled doors), stair cases.

Creating barrier-free architecture is one of the topical problems in building an accessible architectural environment for children with disabilities. This factor should take into account the needs of those children who require specific conditions, who have trouble in self-care and mobility. The first and most important requirement for creating a barrier-free environment is the concept of -universal design $\|$. The principle of this concept is the environment of treatment, education and living, in particular architectural one, must be adapted to the real capabilities of all the categories of the population. The -universal design\| of the architectural environment implies a set of actions to ensure the accessibility, versatility and ecological expediency of the human environment by the architectural means.

The second most important requirement is acting according to a continuity principle of the barrier-free architectural environment. No barriers, the elements, that make impossible or significantly complicated movement and self-care, should be encountered in all the spheres of human 
activity, and first of all in the path of movement. It is especially important to follow the continuity principle in the areas where the child is most often. The accessibility of the environment is not only the release of the barriers when moving through the territory of the rehabilitation center, but also providing the access to all the rooms of the center, furniture and equipment, easy movement from the center to the outside and back [5, p.13].

Based on the analysis of national and foreign practice of design, construction and operation of rehabilitation centers, and taking into account the experience of experimental design and reconstruction of buildings with accessibility for children with disabilities, it is considered appropriate to prioritize the criteria of barrier-free architecture; safety; informatively; comfort.

The accessibility criterion should include:

- the possibility of barrier-free and convenient movement of small-mobile groups around the surrounding area or rehabilitation center;

- $\quad$ barrier-free entrance to the rooms (there must be a stair case as well as a standard ramp);

- $\quad$ open doorway;

- $\quad$ unobstructed movement along the communication paths, rooms both in the building and on the school surroundings;

- the opportunity to use recreation and service areas;

- $\quad$ approaches to different equipment and furniture;

- $\quad$ bathrooms (toilets and showers) for the people with disabilities [5, p. 13] .

Horizontal and vertical communications have a great influence on the architecture of children's rehabilitation centers. Horizontal communications, that provide the connections between different groups of the rooms within a floor, include entrances, halls, galleries, connecting passages, and recreations. Vertical communications include stairs, ramps, elevators.

Special attention should be paid to the organization of the entrance area. In the rehabilitation center the entrances must be adapted for children with disabilities, from the ground level and any pedestrian tunnel or airbridges connected with the center building. The best mode is to arrange the entrance area on a level with the ground without doorsteps and ramps. Door openings should not have doorsteps and difference of floor level. The stairs adapted to the needs of the children with disabilities in the rehabilitation centers should have adequate lighting and handrails.

The psycho-physiological environment has a very big influence on the interior design of the rehabilitation centers. Ensuring physical accessibility at the medical establishments helps to avoid and reduce visitors' anxiety and stress. Wide doorways and halls will promote mobility and accessibility for all the users, as well as make high air circulation that minimize medical professional fatigue. Flat entrance, lowering the reception desk, accessible emergency exits for everybody will help to create an accessible, convenient, safe environment [6, p.14].

It should be noted that the use of such elements as paintings, reproductions, photos, music, color, can significantly improve the mental health of patients and affect the working efficiency of the staff. However, when choosing colors for walls, doors, furniture, for the purpose of special marking, it is necessary to take into account the difficulties in their discrimination for many people, in particular, for elderly patients, patients with mental disorders and those who have color discrimination [6, p. 14].

Medical equipment, that is easy to transform and takes into account the different levels of users' mobility, will help to create comfortable, safe conditions and lighten the work of the staff. For example, a height-adjustable specialist seating is accessible for the children with muscleskeleton disorder and, at the same time, reduces staff efforts [6, p.15].

To make it easier to find the consulting rooms, you can use color marking of different functional rooms and show the way with the help of the arrows of different colours. For the children, colour differentiation is the best guideline. Colour separation of the walls, floors, doors, furniture 
helps to navigate children with visual disorders, as well as attracts attention and prevents the fall and injury of the patients [6, p. 15].

State building codes and design guides help the architects and designers make space for the children with disabilities as accessible, comfortable, and understandable as possible. Nowadays, universal design in our country is at the level of development, but this is the first steps towards improving the architectural environment for children with disabilities.

Conclusions of the basic material and prospects for further development. It follows from the above that the application of ergonomic requirements in the field of environmental architectural design highlights the problems of architectural ergonomics associated with the formation of the immediate surrounding of the children with disabilities, in accordance with the individual requests of the child, taking into account the relief of life functions.

Ergonomic factors influencing the formation of architecture can be divided into 4 groups: spatial and anthropometric requirements (dimension and size of the equipment and the furniture, geometric parameters of space, spatial human behavior, anthropometric characteristics of a person), number of stories in a building (traveling speed of sick children, change of child's body function during walking up, change of temperature and air condition on high floors), barrier-free architecture (the concept of universal design, continuity of barrier-free architectural environment, the position of horizontal and vertical connections), psycho-physiological environment (acoustic and lighting environment, architectural and artistic image, flexibility of the environment).

The implementation of existing design and development rules, as well as adherence to the basic principles of -universal design $\|$ will help to build an architectural environment that includes a set of actions to provide the children with disabilities with architectural accessibility, versatility, flexibility and environmental friendliness.

\section{LITERATURE}

[1] Burikina G. A., Architectural principles for designing buildings for social and psychological assistance to children (for radiation contaminated territories): autoref. Dis. For PHD CNIIEP of housing. - M. $1999 \mathrm{y}$.

[2] Shklyar S.P. Ergonomics in architecture. Harkiv, HNUMG the name of O.M Becketova. 2019 .

[3] Stepanov V.K. Specialized education and medical centers. M.,Stroyizdat. - 1987y.

[4] Ivasenko V.V., Litvinenко T.P., Classification of barrier-free elements of the street-road network and requirements for them. Vestnik HNADU, comp. 63, 2013y.

[5] Educational manual «Architectural accessibility of schools». Kiev-127, VGSPO «National Assembly of Disabled People of Ukraine », 2012y.

[6] Bayda L., Ivanova O., Universal design in medical institutions: method. manual / / - K.: Vaite, 2019y. 